\title{
A magyar lakossági állampapírpiacon érvényesülő viselkedési tényezők*
}

\author{
Kutasi Gábor - György László - Szabó Krisztina
}

Már jó ideje tudjuk, hogy a pénzpiaci szereplök döntéshozatala eltér a tankönyvi modellek által vázolt mintától. A tanulmány a viselkedési pénzügyek felöl közelítve igyekszik feltárni a valós folyamatokat, és a viselkedési pénzügyek téziseinek szakirodalmára alapozva elemzi a magyar lakossági állampapír-vásárlók hipotetikus befektetési döntéseit. Az elemzés egy reprezentativ közvélemény-kutatás eredményeit használja fel, a viselkedési pénzügyek állampapírpiacokra vonatkozó elméletének bázisán. A kutatás kiterjed a döntések mögötti politikai, érzelmi és tájékozottsági háttérre. Vizsgálja a nyájhatást és a demográfiai tényezők befolyását. Új eredményként felvázolja a magyar lakossági befektetők profilját. További újszerü eredménye, hogy adatfelvétellel megerösít bizonyos, jól ismert feltételezéseket a lakossági befektetők viselkedéséről, s áttekinti és szintetizálja azt a viselkedési pénzügyi szakirodalmat, amely kifejezetten az állampapírpiacra vonatkozik.

Journal of Economic Literature (JEL) kódok: D91, G11, G41

Kulcsszavak: viselkedési pénzügyek, állampapír, lakossági befektető, nem racionális döntéshozatal

\section{Bevezetés}

Tapasztalati úton már jó ideje közismert, hogy a pénzpiacokon nem úgy zajlanak a döntések, ahogy azt a tankönyvi modellek vázolják. A tanulmány a magyar lakosság hazai állampapírpiaci viselkedését, gondolkodásmódját tárja fel. Kiinduló feltevésünk szerint a lakosság nem kizárólag a hozamok maximalizálása alapján dönt. A tanulmány újszerü eredménye, hogy a viselkedési pénzügyek állampapírpiaci vonatkozású szakirodalmát áttekintve és erre alapozva reprezentatív közvélemény-kutatáson

\footnotetext{
* Jelen cikk a szerző nézeteit tartalmazza, és nem feltétlenül tükrözi a Magyar Nemzeti Bank hivatalos álláspontját.

Kutasi Gábor (PhD, Dr. habil.) a Századvég Gazdaságkutató Zrt volt elemzője, a Budapesti Corvinus Egyetem docense, a Magyar Nemzeti Bank kutatója, kutatási tevékenységét támogatta a KÖFOP-2.1.2VEKOP-15-2016-00001.E-mail: gabor.kutasi@uni-corvinus.hu

György László (PhD) a Századvég Gazdaságkutató Zrt. vezető közgazdásza, a Neumann János Egyetem docense. E-mail: gyorgy@szazadveg.hu

Szabó Krisztina a Budapesti Corvinus Egyetem tanársegéde és a BCE Nemzetközi kapcsolatok doktori program hallgatója. E-mail: krisztina.szabo11@uni-corvinus.hu
}

A magyar nyelvű kézirat első változata 2017. szeptember 21-én érkezett szerkesztőségünkbe.

DOI: http://doi.org/10.25201/HSZ.17.1.110136 
keresztül elemzi a magyar lakossági állampapír-vásárlók hipotetikus döntési viselkedését.

A kutatás kiterjed a döntések mögötti politikai, érzelmi és tájékozottsági háttérre. Vizsgálat tárgya továbbá a nyájhatás és a demográfiai tényezők befolyása. A szakirodalom alapján definiálásra kerültek a lakossági állampapírpiac keresleti oldalának viselkedését befolyásoló tényezők. A tanulmány kézzelfoghatóvá teszi, hogy hogyan változtatják állampapír-portfoliójukat a hazai lakossági befektetők nemzetközi hatások és feltételezhetően piacformáló befektetők lépéseinek hírére. Következtetéseket von le a nem racionális döntéshozatal, valamint a túlzott kockázatvállalás és kockázatkerülés mértékére vonatkozóan.

A tanulmány új eredményként felvázolja a magyar lakossági befektetők profilját. További újszerü eredmény, hogy adatfelvétellel megerősít bizonyos, jól ismert feltételezéseket a lakossági befektetők viselkedéséről, valamint olyan viselkedési pénzügyi szakirodalom-áttekintőt szintetizál, amely kifejezetten az állampapírpiacra vonatkozik.

Kifejezetten relevánsak az eredmények egy olyan gazdaságpolitikai és államadósság-stratégiai környezetben, amely preferálja, hogy az állampapírok jelentős része a hazai lakossági befektetőkhöz kerüljön a külföldi vevőkkel szemben.

\section{Módszertan}

A viselkedési pénzügyek eddigi eredményei azt mutatják, hogy a háztartási befektetők egyéni és társadalmi jellemzői (pl. nem, anyagi helyzet, életkor, családi állapot stb.) befolyásolják a megtakarítási hajlamot és a befektetési portfolió összetételét. Az államkötvénypiacon tehát nem csupán a kamatszint határozza meg a kötvénykezelés sikerességét és költségét. A kutatást a következő kérdés vezette: A magyar lakosság körében milyen jellemzők befolyásolják az államkötvény-keresletet?

\section{A vizsgálat módszere a következö:}

Összegyűjtöttük a befektetéseket meghatározó tényezőket, amelyből kiindulva saját kérdéseket állítottunk össze közvélemény-kutatás céljára, és reprezentatív mintán két kérdőíves felmérést végeztettünk a magyar lakosság körében a megtakarítási szokásokról, a kockázatvállalásról. A felmérést és ebből az adatbázis összeállítását a Századvég Alapítvány munkatársai végezték. A kérdőíves felmérést szükséges volt több fordulóban elvégezni, mert a kérdések száma meghaladta a telefonos felmérés lehetőségeit.

Az első kérdőív módszere a következő volt: Közvélemény-kutatást végezetünk a felnőtt magyar lakosság körében 2016. október 18-24. között, amelynek során 2002 véletlenszerűen kiválasztott, felnőtt korú személyt kérdeztünk meg CATI-módszerrel 
(Computer Assisted Telephone Interviewing). Az elemzésben közölt adatok legfeljebb plusz-mínusz 2,2 százalékponttal térhetnek el a mintavételből fakadóan attól az eredménytől, amit az ország összes felnőtt lakosának megkérdezése eredményezett volna.

A második kérdőív módszere a következő volt: Közvélemény-kutatást végeztünk a felnőtt magyar lakosság körében 2016. október 22-29. között, amelynek során 2005 véletlenszerűen kiválasztott, felnőtt korú személyt kérdeztünk meg CATI-módszerrel. Az elemzésben közölt adatok legfeljebb plusz-mínusz 2,2 százalékponttal térhetnek el a mintavételből fakadóan attól az eredménytől, amit az ország összes felnőtt lakosának megkérdezése eredményezett volna.

A lakossági kérdőívek összeállításakor az elméleti fejezetben hivatkozott tanulmányok, valamint a Legg Mason (2015) tájékoztató ötleteit vettük figyelembe. A vizsgálat során felvettük a válaszadók profilját kor, nem, iskolai végzettség, lakhely, önbesorolásos társadalmi státusz, politikai álláspont, munkaerőpiaci aktivitás (tevékenység), háztartás létszáma szerint.

\section{Viselkedési pénzügyek az állampapírpiacon}

\subsection{A politikai instabilitás}

A politikai kockázat, politikai stabilitás és bizonytalanság, valamint a politikai átrendeződésnek az informáltságra való hatása miatt befolyásolhatja a befektetői döntések racionalitását. Pantzalis és társai (2000) tanulmányában az értékpapírpiaci mutatókat vizsgálták politikai választások ideje alatt 1974 és 1995 között, 33 ország esetében. A vizsgálódásuk eredménye azt mutatja, hogy a választások előtti két hétben pozitiv, abnormális hozamok jellemzőek a piacon. A tanulmány eredménye összhangban áll Brown és társai (1988), valamint Harrington (1993) eredményeivel, ami szerint bizonyos politikai irányokra érzékeny választásokat nagyobb bizonytalanság kísér, és sokkal nagyobb a manipulációknak való kitettségük. A modell szerint a politikai választásokat kísérő bizonytalanságok az értékpapírok hozamait megemelik.

Moser (2007) tanulmánya arra koncentrál, hogy hogyan hat a befektetők döntésére az adott ország pénzügyminiszterének lemondása vagy elbocsátása. Tizenkét latin-amerikai országot vizsgálva azt találta, hogy a bejelentés napján a kötvény-spreadet pillanatnyi növekedés jellemezte. Ezt követően a spread csökkenése ellensúlyozta bizonyos mértékben a korábbi növekvő tendenciát, azonban a bejelentést követő heteket továbbra is politikai instabilitás jellemezte, ezért a kiinduló állapothoz képest a kötvény-spread nagyobb volt. Huang és szerzőtársai (2015) tanulmányukban a nemzetközi politikai kockázatok hatását vizsgálták az államkötvények hozamára. A szerzők 34 adós ország esetén keresztül 109 nemzetközi politikai krízist 
vizsgáltak. A szerzők pozitív, szignifikáns kapcsolatot találtak a nemzetközi politikai kockázatok és az államkötvények hozama között.

\subsection{Az érzelmi tényező}

A klasszikus pénzügyi elméletekre jellemző, hogy a befektetői érzelmi komponenst teljesen figyelmen kívül hagyják. Az alábbi tanulmányok azonban azt bizonyítják, hogy bár az érzelmi befolyásoltságot nagyon nehéz mennyiségileg mérhetővé tenni, az kétségkívül erős befolyással bír a befektetői döntésekre. Martell (2008) a világ bizonyos országai által kibocsátott államkötvények és az amerikai államkötvények hozamai közötti különbség meghatározó tényezőit vizsgálta, és arra a következtetésre jutott, hogy még a strukturális hitelmodellek által motivált fundamentumok szerinti kiigazítás ellenére is maradtak jelentős, magyarázatra szoruló részei a hozamfelárnak, amelyek egy részét érzelmi tényezőkkel magyarázhatjuk.

Baker és Wurgler (2006) a befektetők érzelmi befolyásoltságát részvénytőzsdei értékpapírokra vizsgálták, amelyek esetében ingadozó mértékben mutatták ki azt, hogy az érzelmek (félelem, eufória) változó intenzitással, de magyarázó erővel bírnak a befektetői döntések esetében. (Hasonló eredményt mutat több korábbi tanulmány is: Kothari - Shanken 1997; Neal - Wheatley 1998; Shiller 2000.) E tanulmányon alapul Laborda és Olmo (2014) elemzése is, amely kifejezetten az USA államkötvényeinek kockázati prémiuma és az érzelmi tényezők közötti kapcsolatot mérte fel. A szerzőpáros azt találta, hogy a hozamgörbén és a benchmark makroökonómiai tényezőin túl a piaci érzelmi tényező is előrejelző erővel bír, azonban ennek prediktív ereje időben változó, és recesszió idején sokkal relevánsabb.

\subsection{Demográfiai tényezők}

Sevic és Brawn (2015) tanulmányában a demográfiai sajátosságok hatását vizsgálja az államkötvények hozamára. Hét fejlett országban a 10 éves államkötvény inflációval korrigált hozamát benchmarkkal vizsgálták, választ keresve arra, hogy a reálkötvény alacsony hozama mennyiben magyarázható demográfiai és nem demográfiai változókkal. Modigliani és Brumberg (1954) úttörői voltak a pénzügyi piac és a demográfiai változók közötti kapcsolat vizsgálatának, amely az életciklus-hipotézisre vezethető vissza. A fiatalabb generáció jövedelmének jelentős részét ingatlanba fekteti be, míg az idősebb generációt megnövekedett megtakarítási hajlandóság jellemzi.

Bakshi és Chen (1994) azt találta, hogy az aggregált fogyasztás és a demográfiai fluktuáció a kockázati prémiumot bizonyos mértékben képes előre jelezni. Az elöregedő társadalom jelensége miatt a tőke jellemzően az értékpapírpiacra áramlik, nem az ingatlanpiacra. Davis és Li (2003) egyes OECD-országok példáján keresztül a demográfiai mutatók és a pénzügyi eszközök ára közötti kapcsolatot vizsgálta. A 40-64 évesek esetében a megtakarítások inkább ingatlan vagyontárgyakban vannak, és azok hozamaiból élnek, míg a 65 év felettiek a kötvényekhez, kötvényhozamokhoz 
köthetők erősen - amely utóbbi részben talán a nyugdíjas korral és a magánnyugdíjpénztárakból finanszírozott nyugdíjakkal is magyarázható, hiszen a nyugdíjalapok főleg kötvényekbe fektethetnek.

Arnott és Chaves (2012) tanulmányának eredménye szerint az értékpapírok elvárt hozama 40 és 64 évesek esetén nő, ez részben magyarázható az életkori sajátosságokkal is, hiszen egy középkorú ember jellemzően sokkal kevésbé bizonytalanságot kerülő, mint egy idősebb befektető. Ennek megfelelően a tanulmány másik konklúziója az, hogy 65 év felett az elvárt hozam csökken. Barber és Odean (2001) a befektető neme és a kereskedelmi aktivitás között tárt fel kapcsolatot, pszichológiai teszt segítségével bizonyítva, hogy a pénzügyi döntések területén a férfiak hajlamosabban szélsőségesen, kockázatosan választani.

\subsection{Földrajzi és kulturális tényezők}

Coval és Moskowitz (1999), Kang (1997), valamint Karlsson és Norden (2007) kimutatta, hogy a portfólió allokációt a földrajzi elfogultság erősen befolyásolja. Amadi (2004) feltevése, hogy az intézményi befektetők külföldi részvények iránti keresletét és így az intézményi portfólió diverzifikáltságát erősen befolyásolják bizonyos tényezők, mint például a közös nyelv, a kereskedelem, a bevándorlási hagyományok. Kang és társai (2010) szerint a külföldi részvények alul- vagy túlértékelését egyrészt a hazai és külföldi befektetők értékítélet-különbségével lehet magyarázni, másrészt a befektetők hazai elfogultságával. Ferreira és Matos (2008) úgy találta, hogy a nem amerikai befektetők gyakran túlértékelik az amerikai vállalatok értékpapírjait. Grinblatt és Keloharju (2001) finn befektetők döntéseit is megatartását vizsgálva arra a következtetésre jutott, hogy a finn befektetők hajlamosak a finn menedzsmenttel rendelkező vállalatokba invesztálni.

Karlsson és Norden (2007) svédországi vizsgálódása szerint a befektető neme és gazdasági nacionalista elfogultságának mértéke között is kapcsolat tárható fel. Felmérésükben a svéd férfiak sokkal elfogultabbak voltak saját országuk kötvényei iránt, mint a nők. Guiso és társai (2004) szerint a másokba vetett bizalom a kulturális beágyazottságtól függ, ami magyarázza a befektetők viselkedését és döntéseit az értékpapírpiacon. Beugelsdijk és Frijns (2010) kutatásának eredménye, hogy a kultúra és kulturális különbségek a portfólió-allokáció diverzifikáltságát nagyban befolyásolják. Power és társai (2009) a nemzeti kultúra fontosságát hangsúlyozzák a kollektivista, feltörekvő ázsiai gazdaságok és az individualista iparosított nyugati nemzetek összehasonlításán keresztül.

Anderson és társai (2011) kutatásukban 60 országot vizsgálnak, az intézményi portfólió változatosságát és a kulturális tényezők hatását tanulmányozzák. A kultúrák közötti eltérő viselkedés országspecifikus változóit bevezetve a szerzők arra a következtetésre jutottak, hogy az eltérő kultúrákból adódó viselkedési különbség magyarázza a külföldi tőke diverzifikációját és a gazdasági nacionalista elfogultságot. 
Különösen azon országok befektetési alapjait jellemzi nacionalista elfogultság és kevésbé diverzifikált befektetés, amelyekben a kockázatkerülő magatartás a jellemző. A kulturálisan zárkózott országok jellemzően zárkózottabbak a külföldi befektetéssel szemben, mi több, a kulturálisan jelentősen eltérő országok piacait hajlamosak figyelmen kívül hagyni. ${ }^{1}$

\section{Lakossági befektetők magatartása a magyar állampapírpiacon}

\subsection{A nem racionális döntéshozatal mértéke}

A lakossági közvélemény-kutatások célja jelen tanulmány esetében az volt, hogy kimutassa a közgazdasági értelemben nem racionális befektetői döntéshozatal jelenlétét a magyar lakosság körében, valamint felmérje ennek nagyságrendjét. A nem racionális döntéshozatal egyik ismérve az információ hiánya. Erre vonatkozóan megkérdeztük, hogy vajon a válaszadók szerint a kormány garantálja-e az állampapírok hozamát és visszavásárlását. A válaszadóknak csak 55 százaléka gondolta/tudta azt, hogy az állampapír mögött állami fizetési garancia áll. Az életkor javította az informáltságot, de így is a 40 feletti korosztály nagyjából 60 százaléka volt csupán tisztában a helyzettel. Az iskolázottság ennél erősebben hat a tájékozottságra, és a felsőfokú végzettségűeknek már 71 százaléka tudott a garanciáról. A magasabb jövedelem, amely szoros összefüggésben lehet az iskolai végzettséggel és egyben a megtakarítási képességgel is, szintén nagyobb tájékozottsággal jár a befektetési kérdésekben. Más informáltságra vonatkozó kérdések válaszaival összevetve szoros kapcsolat fedezhető fel a különböző befektetési eszközök kockázatosságának megítélése és az állami garancia (nem) ismerete között. Akik egy másik kérdésre válaszolva az állampapírt a legkockázatosabb befektetési eszköznek tartották, azoknak több mint kétharmada nem tudott a garanciáról. Azok a válaszadók, akik az állampapírt a legkevésbé kockázatosnak tartják a befektetési lehetőségek között, 90 százalékban tudnak az állami garanciáról. Jól kirajzolódik tehát az alulinformáltságból fakadó irracionális befektetési döntés. Azoknak, akik azért nem fektetnek állampapírba, mert túl kockázatosnak tartják, kevesebb, mint 20 százaléka hallott a garanciáról.

A befektetési eszközök értelmezése során is feltártunk némi értelmezési bizonytalanságot, ami csökkentheti a pénzügyi racionalitást. Arra kértük a válaszadókat, hogy válasszák ki a legkevésbé kockázatos eszközt az alábbi felsorolásból: részvény, államkötvény, vállalati kötvény, arany, ingatlan. A legtöbben az ingatlant nyilvánították a legkevésbé kockázatosnak, második helyen végzett az arany, és csupán harmadik

\footnotetext{
${ }^{1}$ A tanulmány Geert Hofstede (2001) kulturális alapdimenzióit veszi alapul. Hofstede szerint az országok kulturális összehasonlítása öt dimenzión keresztül történhet meg: hatalmi távolság, individualizmus vagy kollektivizmus, maszkulinitás vagy feminimitás, bizonytalanságkerülés, hosszú vagy rövid távú orientáció. Magyarország a hofstedei dimenziókban erősen maszkulin, a bizonytalanságot nagyon kerülő, nagyon individualista és középtávon orientált (pesszimista), viszont a hatalmi centralizációt közepesen nehezen viselő (http://geert-hofstede.com/hungary.html). Összességében nevezhető közepesen távolságtartónak kulturális értelemben.
} 
helyen az államkötvény. Ráadásul erős a gyanú, hogy a válaszadók jelentős része az aranyat mint biztos befektetést úgy értelmezi, mint a maguknál tartható, könnyen mozdítható és fizetésre felhasználható pénzeszközt. Figyelmen kívül hagyják, hogy az arany ára alapvetően a nemzetközi árutőzsdék árfolyamát követi, és alapvetően spekulatív pénzügyi eszköz, amelynek megfelelően ingadozik az árfolyama. Itt is felfedezhető tehát bizonyos kognitív disszonancia. Nem véletlen, hogy az iskolai végzettség ebben az esetben is magyarázó erejü. Kétszer akkora arányban (32\%) nevezték a felsőfokú végzettségűek az állampapírt a legkevésbé kockázatosnak, mint az alapfokú iskolát végzettek (14\%). A jövedelem ez esetben szintén egy irányba mutat a kockázatok megítélésével, ami nyilván abból fakad, hogy a magasabb jövedelműek többször találkoznak megtakarítási lehetőségekkel, és inkább a magasabb képzettségűek közé tartoznak.

A megkérdezetteknek mindössze 37,3 százaléka rendelkezett befektetésekkel. Ennek több mint egyharmada, a válaszadók 13,1 százaléka azt nyilatkozta, hogy nem foglalkozik a befektetései állásával. Igaz ugyan, hogy lehet olyan befektetési konstrukciót kötni, amely nem igényli, hogy a lejárat előtt menedzselni kelljen azt a befektetőnek, ebben az esetben azonban már inkább arról van szó, hogy ezek a válaszadók egyáltalán nem törekednek arra, hogy tisztában legyenek a befektetett vagyonuk értékével, összetételével, lejáratával, ami esetükben nem csak a pénzügyi tudatosság hiányát, hanem az alulinformáltságot, tehát a nem racionális döntéshozói helyzetet jeleníti meg.

A felmérésből megtudtuk, hogy a válaszadók 89 százalékának nem volt magyar állampapírban megtakarítása a megkérdezés időpontjában. A megkérdezettek 62,2 százaléka egyáltalán nem rendelkezett megtakarítással. Nekik feltettük azt a kérést, hogy miért nem. A válaszok megoszlását az 1. ábra összegzi. Ebből kitűnik, hogy 5,4 százalékuk nem ismeri a kondíciókat és a kockázatokat, azaz nem tökéletesen informáltak, 7,8 százalékuk pedig kifejezetten politikai motivációval magyarázza a döntését. A politikai vélemény szembetűnően befolyásolta a válaszokat, mert a magát baloldalinak tekintők 25 százaléka nyilatkozta azt, hogy „ennek a kormánynak nem adom a pénzemet hitelbe”, míg a középre vagy jobboldalra sorolt válaszadók esetében ez 5 százalék körül mozog. Életkori megoszlás szempontjából a legfiatalabbak körében volt a politikai elutasítás a legmagasabb (12,5\%), miközben a megtakarítási képesség körükben viszonylag alacsonyabb. A felsőfokú végzettségűek körében kiemelkedően a legmagasabb a politikai elutasítás (11,3\%), bár a középiskolai végzettségúek 9,9 százaléka sem adná kölcsön a pénzét a kormánynak. A legmagasabb jövedelmúek esetében 10,6 százalék a politikai elutasítás.

Az iskolai végzettség szerinti válaszokat nagyon jól tükrözik a jövedelmi klaszterek szerinti válaszok. A legmagasabb jövedelműek esetében a válaszadóknak csak fele hivatkozott arra, hogy nem tud megtakarítani, 8 százalékuk arra, hogy nem ismeri a kondíciókat, 10,6 százalék a politikai elutasítást, és lényegében összevonva 24,6 százalék máshol keresi a befektetési lehetőségeket, nem az állampapírpiacon. 
A tájékozottság kimutathatóan befolyásolja a vételi szándékot. A vételi szándékra vonatkozó kérdéssel azonos felmérésben szereplő tájékozottsági kérdések eredménye a következő: azok 35 százaléka nem venne magyar államkötvényt, akik - tévesen - azt hiszik, hogy nem kapcsolódik semmilyen adókedvezmény az állampapírhoz, míg azok körében, akik tisztában vannak az adókedvezménnyel, 25 százalék ez az arány. Akik szerint - tévesen - a bankbetétek hozama meghaladja az állampapírét, azok 33,5 százaléka nem fektetne magyar állampapírba, akik pedig - szintén tévesen - egyformának mondták a hozamokat, azoknak a 41,7 százalékára igaz ez a megállapítás. Azok körében, akik tisztában voltak azzal, hogy az állampapírok rendelkeznek magasabb hozammal, csak 26,3 százalékos az elutasítók aránya. Ugyancsak többen, 38,4 százalék utasítja el ezt a befektetési formát azok esetében, akik úgy tudják - tévesen - hogy van díja az állampapír-vásárlásnak, míg azoknál, akik tisztában vannak a díjmentességgel, 24,5 százalék ez az arány.

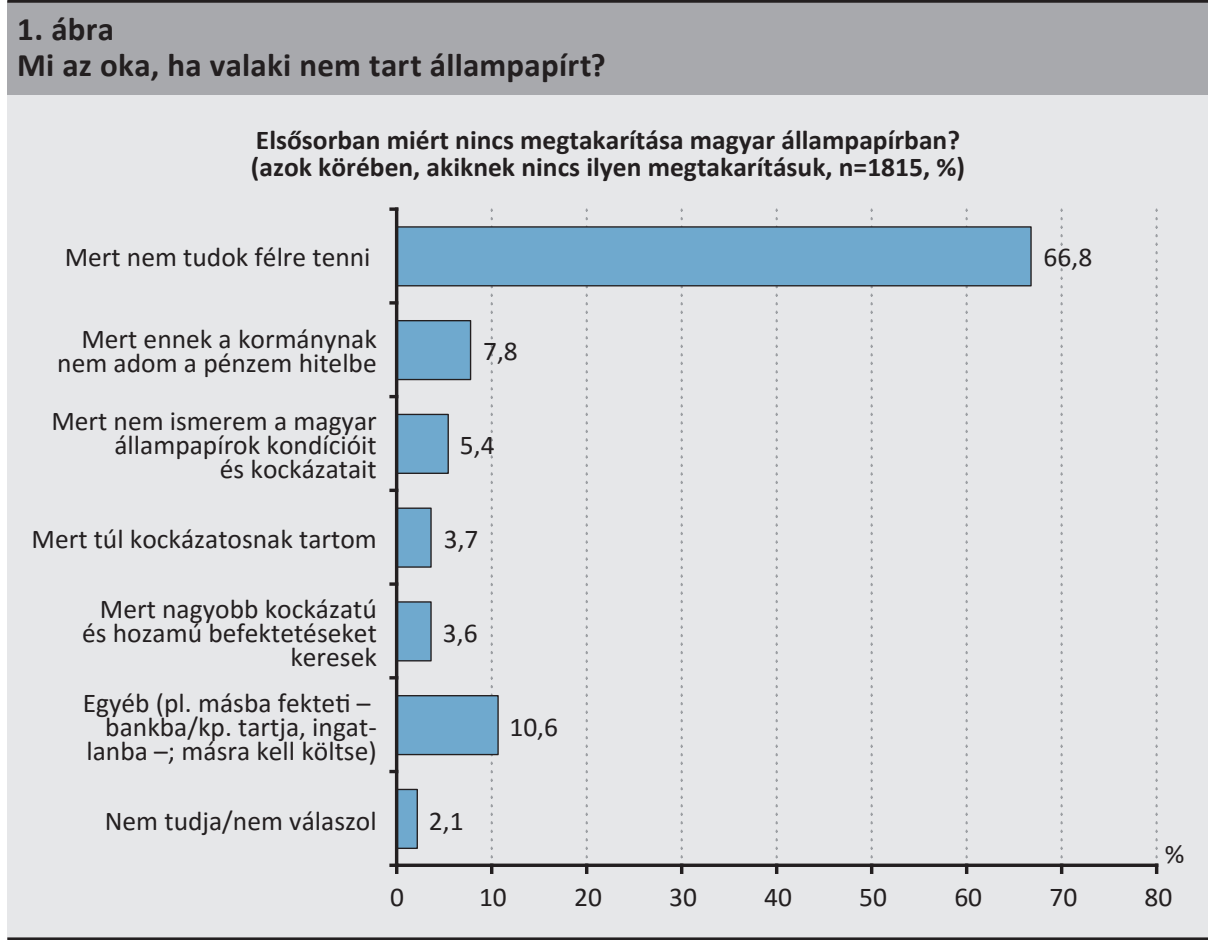

\subsection{Hogyan viselkedik a magyar lakosság befektetési ügyekben?}

A közvélemény-kutatás során vizsgáltuk azt is, hogyan viselkednek egy-egy befektetési élethelyzetben a válaszadók. A válaszok alapján a lakosság 46,7 százaléka automatikusan bankbetétbe vagy állampapírba - a két legkevésbé kockázatos, de likvid befektetésbe - helyezné el megtakarításait. Ebben a kérdésben is jól megmutatkozik a nemek közötti különbség, mert a nőknek 52 százaléka, a férfiaknak viszont csupán 42 százaléka nyilatkozott úgy, hogy ez az attitűd jellemző rájuk. Jelentősen 
eltér a korcsoportok viselkedése a kérdésben: a 18-49 évesek közötti három korcsoport csak 35-38 százalékban nyilatkozott úgy, hogy reflexszerüen bankbetétbe és állampapírba tenné a megtakarítását, míg az 50-59 éves korosztály 44 százaléka, a 60 feletti korosztály 64 százaléka tenne ugyanígy. Utóbbiak esetében tehát az állampapír elsősorban a bankbetéttel versenyez, míg a fiatalabb korosztályok körében magasabb hozamot ígérő, kockázatosabb befektetésekkel szemben kellene vonzerőt mutatnia. Iskolai végzettség szempontjából az éles választóvonal a nyolc általános és a többi fokozat között van. Előbbiek közel 62 százaléka, míg utóbbiak 44 százaléka takarít meg automatikusan a két kockázatmentes lehetőségben. Fontos, megfigyelés, hogy az önálló jövedelemmel rendelkezők esetében az aktívan dolgozók mindössze 37,4 százaléka, viszont a nyugdíjasok 64,3 százaléka azonnal bankbetétben vagy állampapírban tartja a megtakarításait. Jövedelmi szempontból nincs ilyen jelentős szórás.

A következő két kérdésben az mutatkozik meg, hogy a lakosság viszonylag nagy hányada nem hoz felelőtlen befektetési döntéseket. Mindössze 8,3 százalék ugrik „tuti tippre”. Jelentősebb kisebbség, 19 százalék viszont másra bízza a befektetési döntéseket. Igaz, az iskolázottság magasabb foka jelentősen csökkenti a másokra hagyatkozást. A „tuti tipp” esetén a nyolc általánost végzettek esetében 19,5 százalékra ugrik a másra hallgatók aránya, míg a főiskolai végzettségűek esetében ez az iskolai fokozatokkal nagy lépésekben 2,8 százalékra csökken. A befektetési döntés másra hagyása esetében kisebb szórással, de egyértelmű kapcsolat figyelhető meg az iskolai végzettséggel. 6,5 százalékpontnyi különbség van a nyolc általánost (21,8\%) és a főiskolát/egyetemet végzettek (15,3\%) között. A végzettségi fokon felfelé lépdelve egyenletesen csökken az arány. Ugyanakkor a saját mérlegelésről lemondó két forma között nagyon kicsi az átfedés. Kevesebb, mint tizede fogad el „tuti tippet” azonnal azok közül, akik másra bízzák a döntést, akik pedig gondolkodás nélkül a „tuti tippbe” fektetik a pénzüket, csak 22 százalékban nyilatkoztak úgy, hogy általában másra bízzák a befektetési döntéseket. (Noha mások javaslatainak feltétlen elfogadása tulajdonképpen azt jelenti, hogy másra bízzák a döntést.)

A lakossági válaszadókat különböző döntéshozatali helyzetek elé állítottuk, hogy szimuláljuk, hogyan reagálna az állampapír-keresletük eltérő sokkhatásokra. A megtakarítási hajlandóságukat és horizontjukat nem csak azzal mértük, hogy a jelenlegi jövedelmükből mennyire tudnak/nem tudnak félretenni és állampapírba fektetni, hanem megkérdeztük, hogy ha most kapnának egymillió forintot, milyen időtávra takarítanák meg. A válaszadó lakosság negyede egyáltalán nem tudná, vagy nem akarná megtakarítani, és gyakorlatilag közel egyharmaduk a hathetes lakossági kincstárjegy lejáratát sem tudná kivárni. Alig több mint 58 százalékuk tudna a jelenlegi jövedelmén túli váratlan összeget legalább 1 éves állampapírba fektetni, de ebből csak 12,4 százalék tudná hosszú távra, öt éven túl nélkülözni ezt az összeget. Alapvetően a jövedelmi és az ezzel összefüggő kereső státusz határozza meg az ettől való eltérést. A magasabb jövedelműek hosszabb távra tudnák félretenni az extra bevételt (2. ábra). 


\section{2. ábra}

\section{Megtakarítási időtáv döntési helyzete}

Ha most kapna egymillió forintot, mennyi időre tenné félre megtakarítási célból? (\%)

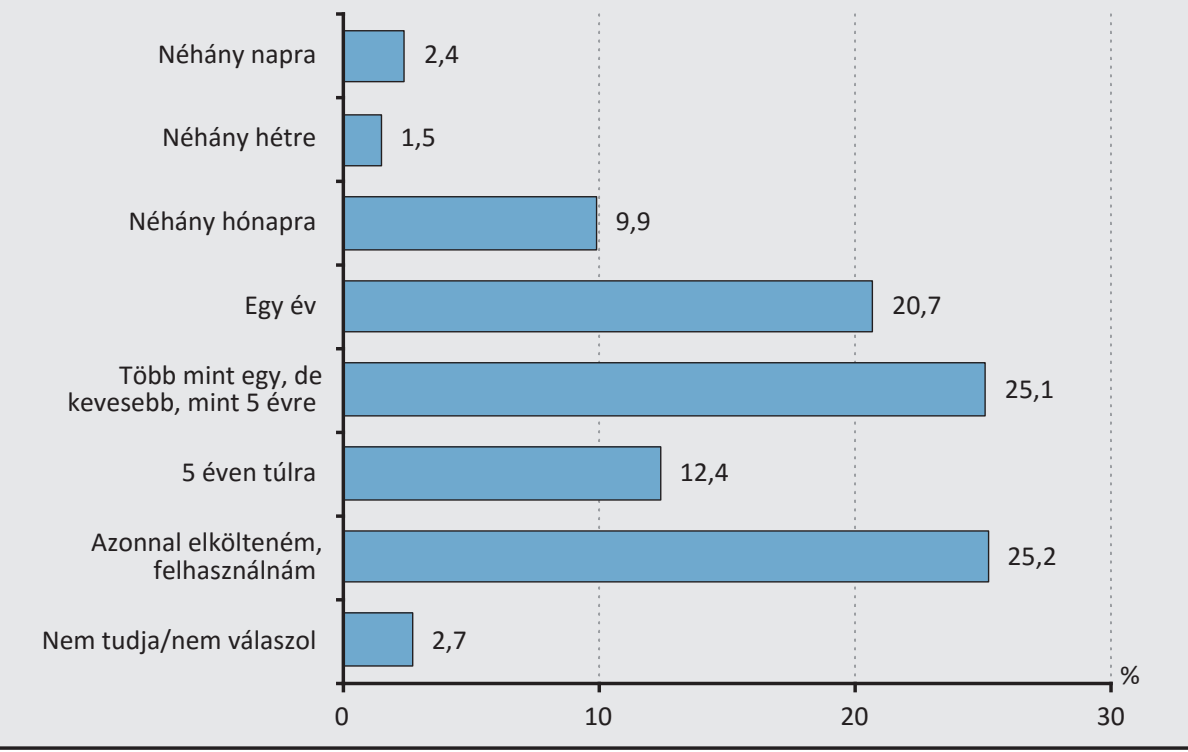

\section{3. ábra}

\section{A lakosság megtakarítási eszközpreferenciája}

Tegyük fel, hogy van tízmillió forintja.

A megtakarítás melyik módját választaná az alábbiak közül öt éves időtávban? (\%)

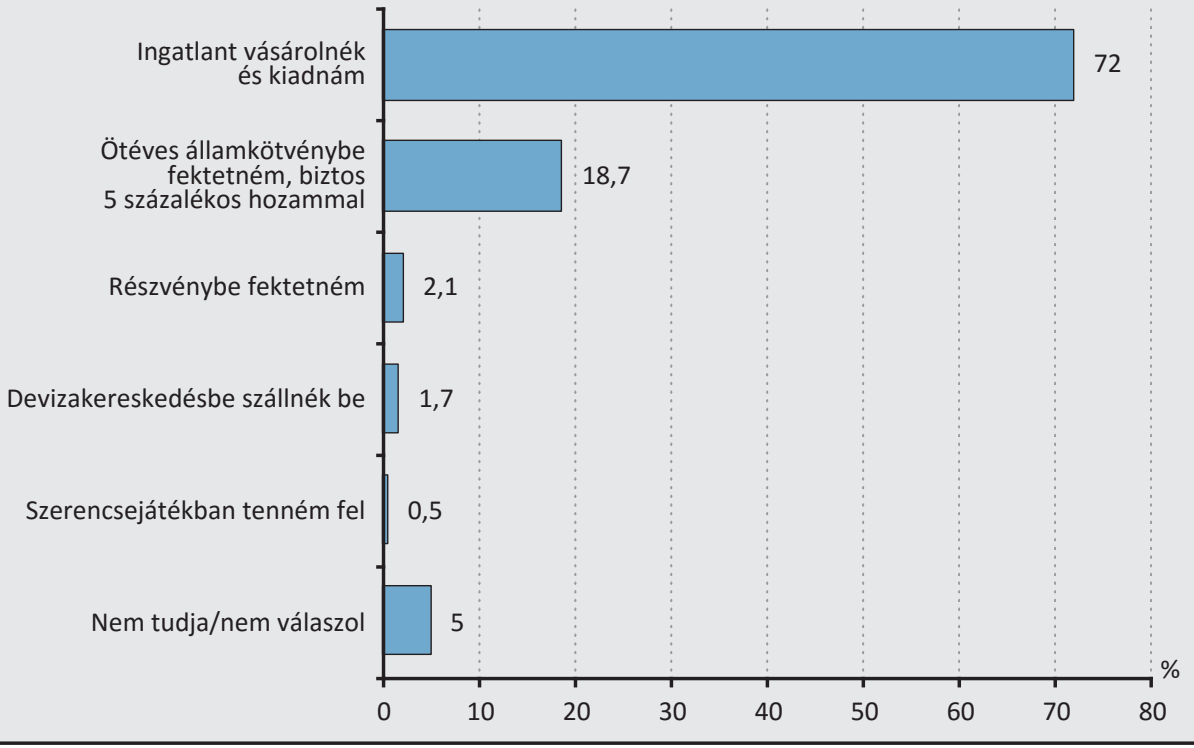


Amikor azonban időtávtól függetlenül nagyobb befektethető összegre kérdeztünk rá, akkor az derült ki, hogy a lakosság túlnyomó többsége (72\%) ingatlanba fektetne nagyobb vagyonokat, amely esetében nincs igazán szükség olyan jellegű pénzügyi ismeretekre és átlátó képességre, amelyet a kötvény-, részvény- és devizapiacok igényelnek (3. ábra). Ezt persze befolyásolhatja a 2016-ban bekövetkezett magyarországi ingatlanár-emelkedés és az ezzel párhuzamosan alacsony állampapírhozamok. ${ }^{2}$ Ezzel együtt az állampapír 18,7 százalékkal a második helyen szerepel. A többi lehetőség gyakorlatilag jelentéktelen mértékű szavazatot kapott. E tekintetben tehát újra megmutatkozik a lakosság kockázatkerülő, felelős megtakarítói magatartása.

A kockázatvállalási hajlandóságot oly módon mértük, hogy megkérdeztük a lakossági válaszadókat, milyen kockázati mértékig lépnének ki a viszonylag biztos hozamú állampapírból magasabb hozam reményében. Azt kérdeztük, hogy ha 1 millió forintja van állampapírban, és egy olyan üzleti ajánlatot kap, amely során ugyanolyan eséllyel ér el magas hozamot, mint amilyen eséllyel ugyanekkora mértékű veszteséget, akkor eladná-e az állampapírt. A kérdést feltettük +/-33 százalékos és +/-10 százalékos nyereség/veszteség kimenetre. A 10 százalékos nyereség és veszteség lehetőségre még bátrabban mozdulnának a lakossági befektetők, de ez esetben is kevesebb mint egyharmaduk adná el az állampapírt. A növekvő kockázat (és nyereség/veszteség kimenet) pedig eltántorít, és kevesebb válaszadót ösztönöz kockázatvállalásra. Kijelenthető, hogy a lakosság túlnyomó többsége nem adja fel a biztos hozamot a nagy kockázattal járó, magas hozamígéretekért cserébe. Az állampapírban igazán megtakarító magasabb jövedelmi réteg esetében azonban magasabb a kockázatvállalási hajlam, hajlandó a magasabb megtakarítási képesség mellé nagyobb kockázatú portfóliót rendelni. Amíg az 50 és 100 ezer forint egy főre jutó jövedelmú háztartások közül csak 14-17 százalék vállalná be a +/-33 százalékos kimenetet és 23-28 százalék a +/-10 százalékos kimenetet, addig a 100 ezer forint/fő feletti háztartások válaszadói 22, illetve 32 százalékban válaszolták azt, hogy eladnák a biztos állampapírt a kockázat vállalása érdekében. Életkor szempontjából viszont a korral együtt csökken a kockázatvállalási hajlandóság mindkét hozamlehetőség esetében. A nemek szerinti bontás megerősíti a fent tett állítást, amely szerint a férfiak kockázatkeresőbbek, míg a nők a biztonságosabb befektetési portfóliót preferálják.

A két különböző nyereségszint melletti kockázatvállalók között nincs teljes átfedés, azaz, aki hajlandó a kisebb veszteséget kockáztatni kisebb nyereség reményében, az nem feltétlenül vállalja be a nagyobb nyereséget nagyobb kockázat mellett, illetve fordítva, aki hajlandó a nagy nyereségért nagy kockázatot vállalni, nem biztos, hogy kisebb nyereség, kisebb kockázat mellett is a kockázatosabb lehetőséget választja.

\footnotetext{
${ }^{2}$ Lásd MNB-Lakásárindex http://www.mnb.hu/statisztika/statisztikai-adatok-informaciok/adatok-idosorok/ vi-arak/mnb-lakasarindex és MNB - Állampapírok aukciós átlaghozama http://www.mnb.hu/statisztika/ statisztikai-adatok-informaciok/adatok-idosorok/xiii-ertekpapirok-es-tokepiaci-informaciok
} 
Azoknak, akik a 10 százalékos nyereség/veszteség kimenetre igent mondtak, csupán 41 százalékuk vállalta a 33 százalékos nyereség/veszteség kimenetet. Azok közül továbbá, akik a 33 százalékos nyereség/veszteség kimenetre már átcsoportosítanák a biztos befektetésüket, csupán 58 százalékuk mozdulna meg a kisebb nyereség/ veszteség kimenetű ajánlatra is. A tökéletes piacot és racionális döntéshozót feltételező elméleti modellben a döntéshozó kockázatsemleges. ${ }^{3}$ A közvélemény-kutatás konkrét döntési helyzeteinek várható értéke - azaz vagy nyerek, vagy veszítek 50-50 százalék valószínúséggel - a valószínúséget figyelembe véve nulla. Egy racionális, kockázatsemleges szereplő a két különböző kimenetelű (10 és a 33 százalékos nyereség/veszteség), de mégis azonos várható értékű alternatív befektetési lehetőségre azonos módon kellene, hogy reagáljon. A felmérésben nem ez történt. Ráadásul a nem modellszerű reakció már abban is megmutatkozik, hogy a biztos 5 százalék hozamú befektetést a válaszadók negyede/ötöde feladná egy nulla várható értékű befektetésért.

\subsection{Tökéletlen informáltság, nyájhatás}

A felmérés során megfigyelhető volt, hogy a lakosság egy része nem feltétlenül a tökéletes informáltságra törekszik, továbbá, hogy mások véleményére hagyatkozik befektetési kérdésekben. A válaszadók 17,8 százaléka megérzéseire hallgat, 14,9 százaléka pedig hozzá közelálló személyek javaslatai szerint cselekszik, ami a nyájhatás megnyilvánulásaként értelmezhető. Bár feltételezhetjük, hogy a pénzügyi szakember és a bank tájékozott a befektetési kérdésekben, a velük való konzultációt (9,5 és 1,7\%) tekinthetjük követő magatartásként. Legfeljebb annyi a különbség, hogy akit követnek, az tökéletesen vagy legalábbis széleskörűen informált (4. ábra).

Koreloszlás szempontjából a két szélső véglet, a 18-29 évesek és az 50 év feletti korcsoportok hajlamosak inkább saját megérzéseikre hallgatni (17-21\%), míg a megtakarítóképesebb 30-49 közötti korcsoportok esetében ez 10-15 százalékos szinten mozog. Érdekes, hogy ugyanebben az utóbbi korcsoportban a legmagasabb az internetről tájékozódók aránya (a harmincasok esetében 51 százalék, a negyvenesek esetében 42 százalék) és nem az Y generációba sorolt 18-29 évesek körében (40\%). A közeli barátok és ismerősök tanácsa leginkább a legfiatalabbak körében számít, egynegyedük elsősorban tőlük tájékozódik. Az idősebb korcsoportokban azonban ez már csak 12-14 százalék körül mozog. Az egy före jutó jövedelem esetében a jövedelemmel arányosan növekszik azok aránya, akik pénzügyi tanácsadóval és bankkal konzultálnak, illetve akik az internetről tájékozódnak. A megtakarítási képesség növekedésével tehát javul az informáltsága a lakosságnak, és csökken a nyájhatás érvényesülése.

\footnotetext{
${ }^{3}$ A kockázatsemlegességről bővebben: Markowitz (1959), Merton (1972), Medvegyev (2009), Medvegyev (2010).
} 
Csoportszociológiából ismert jelenség, hogy az egyének döntését befolyásolhatják a hozzá közelálló személyek vagy a csoport hangadói. Megkérdeztük a válaszadókat, hogy hozzá közelálló személy véleménye megváltoztatná-e a befektetési preferenciájukat. A válaszadók közel 17 százaléka felelte azt, hogy valószínúleg vagy biztosan megváltoztatná, tehát esetükben meglehetősen biztosan kijelenthető a követő magatartás. Ezenkívül a válaszadók több mint negyede nem biztos abban, hogy nem változtatná meg a döntését. Tehát úgy tűnik, hogy igen jelentős arányban reagál potenciálisan a lakosság az informális befektetési információkra, ha az hozzá közelálló személytől érkezik, azaz erős a csoportdinamika a befektetési döntések terén. A kérdés kapcsán nem lehet különösebben csoportjellemzők alapján elkülöníteni, hogy kik hajlamosabbak mások véleményére hallgatni.

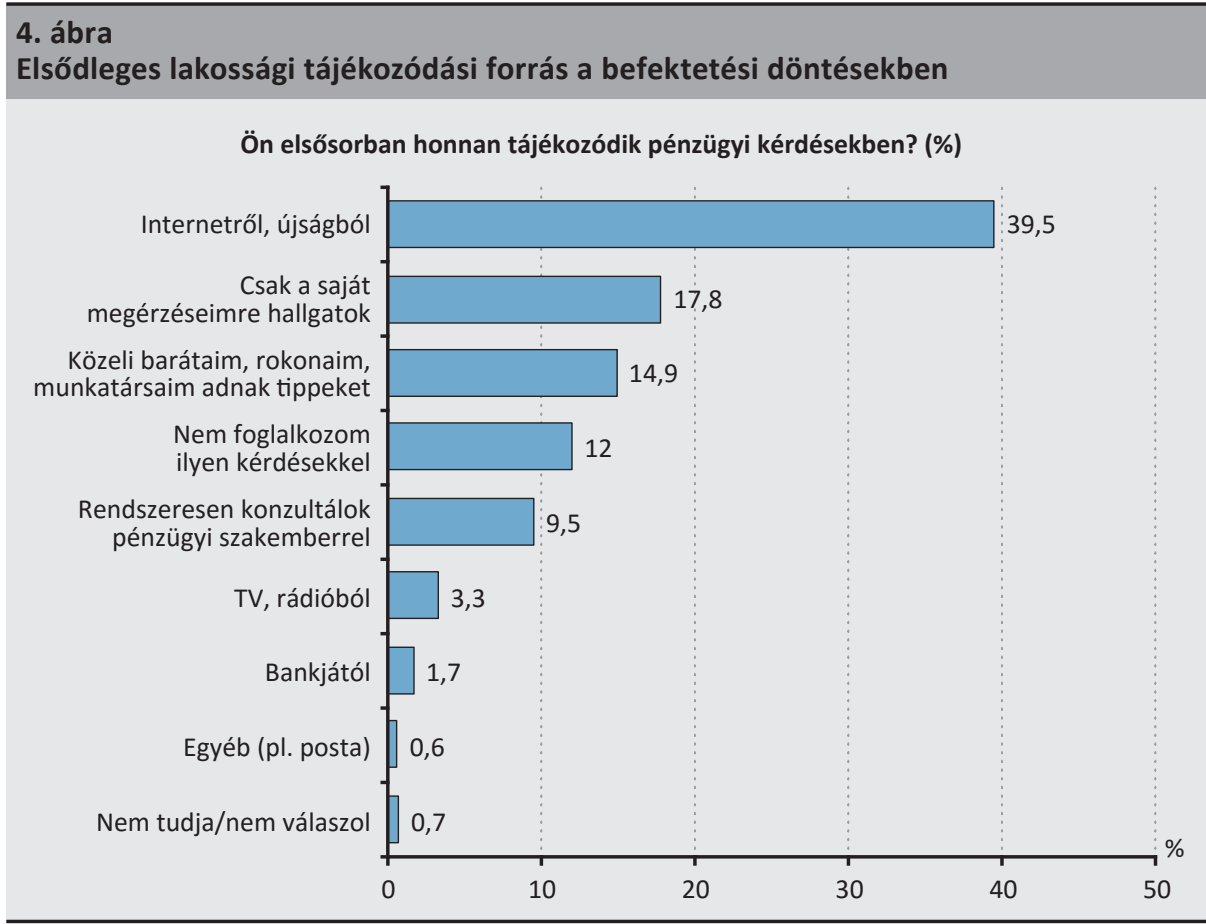

Hat kérdésben vizsgáltuk azt, hogy mit tennének a befektetők, ha egy nemzetközi piaci esemény következne be, vagy egy befektetési véleményvezér tenne valamit (5. ábra). Az állampapír leminősítése viszonylag egyértelmű, hiszen közvetlenül kötődik a befektetéshez. Ebben az esetben a lakossági befektetők nagyjából azonos arányban tartanák és eladnák (43,7, illetve 43\%) papírjaikat. A nemzetközi hatások esetén a negatív világgazdasági sokkban komolyabb kockázatot lát a lakosság, mint egy regionális görög fizetésképtelenségben. Egy újabb görög válság esetén közel 60 százalék nem változtatna a magyar államkötvény-pozícióján, míg globális visszaesés esetén már csak kevesebb mint a fele tartana ki. Érdekes, hogy mindkét sokk esetében, sőt a leminősítéskor is lenne, aki inkább növelné magyar állampapír-állományát. Vagy arra kell gondolnunk, 
hogy hozamnövekedésre várnak, vagy arra, hogy menekülési eszközként tekintenek az állampapírra. Jellemzően a fiatalabb, a felső jövedelmi kategóriájú és - a görög válság kivételével - a közép és felsőfokú végzettségűek körében súlyozódik felül a vételre is hajlandók aránya. Ezek jellemzően a tájékozottabb befektetők jellemzői.

A nyájhatás mérése érdekében vetettük fel, hogy mit tennének a válaszadók, ha neves befektető, a piaci szereplők többsége vagy a megbízhatóság és prudencia szinonimájaként is értelmezhető „német” intézményi befektető veszi az állampapírt. Mindegyik hír képes megmozgatni az állampapírpiacot, de úgy tűnik, hogy a lakosság több mint fele nem változtatna állampapír-pozícióján. A német szereplő és a magyar háztartások vételére a válaszadók közel ötöde követné a mintaadó magatartást, míg a neves befektetőre alig 10 százalék reagálna ugyanígy. Ezzel párhuzamosan a válaszadók negyede/ötöde ellentétes múveletet, eladást hajtana végre mindhárom esetben. Hogy ez a hozamgörbe-csökkenésre vonatkozó racionális, végiggondolt várakozás, vagy valamilyen egyéb ok miatt következne be, nehéz megmondani a felmérésből. Az mindenesetre biztos, hogy a magasabb jövedelmúek és a középfokú, de több esetben (neves befektető, német intézményi befektető) a felsőfokú végzettségűek is hajlamosabbak átlag feletti mértékben követni a véleményvezérlő piaci szereplő(ke)t. Érdekes, hogy a magukat átlag feletti teljesítményü befektetőnek tartó válaszadók nagyobb arányban (15-30\%) követik a fenti szereplőket.

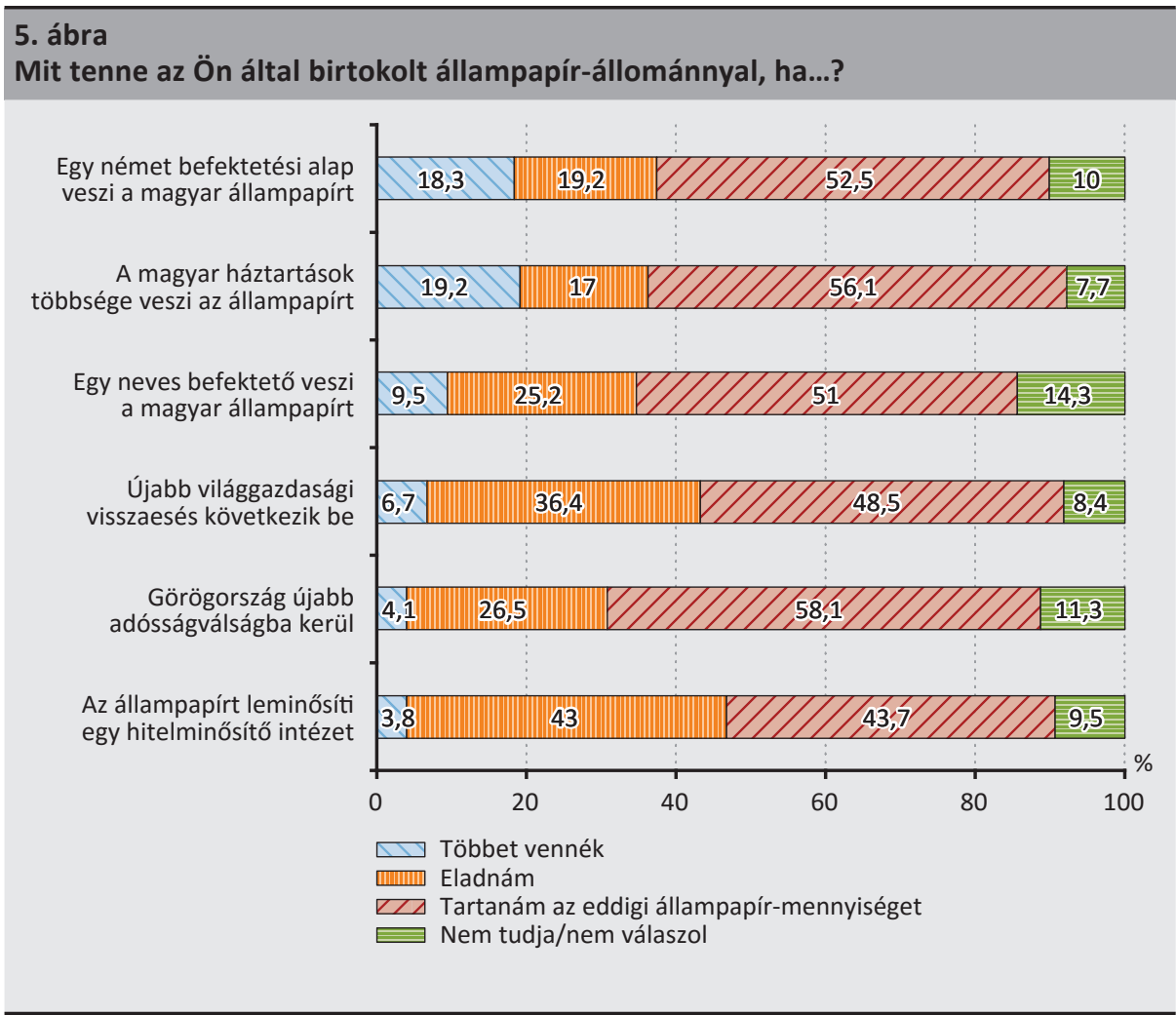


A három véleményvezérre való reakcióban sincs teljes átfedés a döntések között. A német intézményi befektető döntését másolóknak csak 26 százaléka másolja a neves befektető döntését, de 45,5 százaléka a magyar háztartásokat is követi. A neves befektető döntését másoló válaszadók 39 százaléka másolná a magyar háztartások lépését is, és 50 százaléka a német befektetési alapét is. A magyar háztartásokat másolók 43 százalékban követnék a német, és csupán 20 százalékban a neves befektető döntését. Sokkal szignifikánsabb az átfedés az állampapír-pozíciójukon nem változtatók esetében, mert ott minden esetben 70-75 százalék az átfedés aránya. A véleményvezérekkel ellentétesen, eladásban gondolkodók esetenként 50-65 százalékban fednek át. (Kivéve a neves befektető vételi szándékára eladással reagálókat, mert ők a magyar háztartások vételi szándékára eladással reagálókkal csak 42 százalékban fednek át.)

\subsection{A nemzeti érzület dimenziója}

A szakirodalom alapján úgy túnik, hogy jelentősége van a gazdasági nacionalizmusnak, avagy a nemzeti érzületnek az állampapírpiacon is. A közvélemény-kutatás során azt a kérdést tettük fel, hogy a válaszadó egyetért-e azzal, hogy egy magyar embernek hazafias kötelessége magyar állampapírt venni? Úgy túnik, hogy a lakossági válaszadók több mint negyede egyetért ezzel, tehát ez az érzületi hatás is tényező az állampapírpiacon, ami újabb példája annak, hogy a lakossági befektetők egyes köreinek viselkedését magyarázó tényezők túlmutatnak a hozammaximalizáló gazdasági racionalitáson. A 60 év feletti válaszadók (és ezzel együtt a nyugdíjas státuszúak) körében kiugróan magas, 38 százalékos ennek a véleménynek az aránya. $\mathrm{Az}$ alacsonyabb iskolai végzettségúek körében szintén átlag felett adtak ilyen jellegú választ. (Nyolc általános esetében 31 százalék, szakmunkás és szakiskola esetében 29 százalék.) Jövedelmi szempontból az 50-75 ezer forint/fő jövedelmú háztartások válaszadói közül képviselik legnagyobb arányban, 34 százalékban ezt a nézőpontot. Meg kell jegyeznünk, hogy e csoportok általában inkább az állampapírpiac és úgy általában a lakossági megtakarítások periférikus csoportjai, kevés vagy semmilyen megtakarítással. Tehát őket kevésbé fenyegeti az a veszély, hogy a saját elvárásuknak a gyakorlatban is meg kell felelniük, és hazafias érzületből kelljen állampapírt venniük.

Politikai preferencia szempontjából, bár látszólag a magukat jobboldali szavazónak tekintők szintén kiugró arányban támogatják ezt a megközelítést, de valójában itt inkább az adott, 2016. októberi kormánypárti-ellenzéki felállás és viszony lehet a meghatározó. Ugyanis az ellenzéki pártok közül az MSZP támogatóinak 49,4 százaléka ért egyet ezzel a hazafias kötelezettséggel, amely szignifikánsan meghaladja még a Fidesz-KDNP támogatói között mért 43,4 százalékos arányt is, miközben a Jobbik támogatóinak mindössze 16,7 százaléka értett egyet az állítással, amely több kis baloldali párt arányát is alulmúlja. Hangsúlyozzuk tehát, hogy ebből az a következtetésünk, hogy a pillanatnyi politikai helyzettől függően a politikai preferenciák ebben a kérdésben is mérhetők. 
Érdekes, hogy a negatív hírekre (leminősítés, világválság, görög válság) állampapír-tartással vagy -vétellel reagálók körében is átlag feletti, 30 százalékos azok aránya, akik támogatják a hazafias szempont érvényesülését (5. ábra), továbbá, akik a befektetési alternatívák közül az államkötvényt preferálták (3. ábra), azoknak több mint 42 százaléka szintén egyetért a szempont érvényesülésével.

\section{Következtetések}

A tanulmány gyakorlati eredménye az elmélet tükrében kiértékelt közvélemény-kutatás a magyar lakossági állampapír-keresletről. Teljesen új eredmény a tanulmányban felvázolt magyar lakossági profil. Először is a legáltalánosabb társadalmi és gazdasági jellemző visszaigazolódott ebben a kutatásban is, ami szerint a magyar társadalom nagyjából kétharmada nem rendelkezik megtakarításokkal. A háztartások jelentős részének nincs megtakarítása, és ennek következtében nem is foglalkozik befektetési kérdésekkel. Amely háztartások mégis képesek megtakarítani, azok befektetési időtávja rövid. 58 százalékuk egy éven túli eszközt nem is venne megtakarítási célból. Jó hír viszont az állampapír-forgalmazóknak, hogy ha a megtakarításra még nem képes háztartások jövedelmi helyzete javul a jövőben, akkor, amennyiben képesek lesznek jövedelmük egy részét félretenni, közel 60 százalékban államkötvénybe fektetnének. Nagyobb vagyon esetén viszont a magyar háztartások az ingatlant preferálják az államkötvénnyel szemben.

A tanulmány hátteréül szolgáló felmérésben a megkérdezetteknek mindössze 37,3 százaléka rendelkezett befektetésekkel. Ennek több mint egyharmada, a válaszadók 13,1 százaléka azt nyilatkozta, hogy nem foglalkozik a befektetései állásával, ami bizonyos mértékben már nem feltétlenül tekinthető racionális viselkedésnek. A válaszadók 89 százaléka nem rendelkezett állampapírral, jelentős részük természetesen a megtakarítási képesség hiánya miatt. A megtakarítani tudó válaszadók között is volt viszont olyan, aki információhiány miatt nem fektetett állampapírba. Tehát a tökéletes piac feltevése nem érvényesül teljes mértékben.

Több megközelítésben igazolódott, hogy a háztartások informáltsága korlátozott. A válaszadóknak csak 55 százaléka gondolta/tudta azt, hogy az állampapír mögött állami fizetési garancia áll. Az életkor javította az informáltságot, de így is a 40 év felettiek közel 60 százaléka volt csupán tisztában az állami garancia tényével. Az iskolázottság ennél erősebben hat a tájékozottságra, és a felsőfokú végzettségűeknek már 71 százaléka tud a garanciáról. A magasabb jövedelem, amely szoros összefüggésben lehet az iskolai végzettséggel és egyben a megtakarítási képességgel is, szintén nagyobb tájékozottsággal jár a befektetési kérdésekben. Az adókedvezmények és a hozamok tekintetében sem volt tájékozott a válaszadók teljes köre.

Ugyanakkor nem minden esetben kell az információhiányt tökéletlen piacnak és nem racionális döntési helyzetnek tekinteni. A felmérés során megfigyelhető volt, 
hogy a lakosság egy része nem feltétlenül a tökéletes informáltságra törekszik, továbbá, hogy mások véleményére hagyatkozik befektetési kérdésekben. A közeli barátok és ismerősök tanácsa leginkább a legfiatalabbak körében számít, 25 százalékuk elsősorban tőlük tájékozódik. Az egy főre jutó jövedelem esetében a jövedelemmel arányosan növekszik azok aránya, akik pénzügyi tanácsadóval és bankkal konzultálnak, illetve akik az internetről tájékozódnak. A megtakarítási képesség növekedésével tehát javul az informáltsága a lakosságnak, és csökken a nyájhatás érvényesülése. A beazonosított véleménykövető csoportok pedig az állampapír-értékesítés számára jelentenek feltárt elérési lehetőséget, amelyen keresztül hatékonyabban vonhatók be a véleménykövetők a lakossági állampapírpiac keresletébe.

A különböző attitűd- és preferenciakérdések alapján kijelenthető, hogy a magyar lakosság 90 százaléka biztonságra törekszik befektetési kérdésekben, és nem hozna felelőtlen döntést, ha megtakarítási lehetőséghez jutna. A lakosság kockázatvállalási hajlandóságát úgy mértük, hogy megkérdeztük, milyen kockázati mértékig lépnének ki a viszonylag biztos hozamú állampapírból magasabb hozam reményében. Kijelenthető, hogy a lakosság túlnyomó többsége nem adja fel a biztos hozamot a nagy kockázattal járó, magas hozamígéretekért cserébe. Ez szintén kedvező az állampapír-forgalmazás számára, hiszen erős a kereslet lojalitása az alacsony hozamú, de biztonságos pénzügyi termék irányában. Érdekes módon az állampapírban nagyobb mértékben megtakarító magasabb jövedelmi réteg esetében magasabb a kockázatvállalási hajlam: ők inkább hajlandók a magasabb megtakarítási képesség mellé nagyobb kockázatú portfóliót rendelni.

A kis és nyitott magyar gazdaságban, a kockázati befektetésnek tekinthető forintpiacon érdemes volt megvizsgálni, hogyan reagál a lakosság a nemzetközi piaci hatásokra. Hat kérdésben szimuláltuk azt, hogy mit tennének a hazai lakossági befektetők, ha egy-egy jelentős nemzetközi piaci esemény következne be, vagy egy befektetési véleményvezér tenne valamit. Az állampapír leminősítése következtében nagyjából azonos arányban tartanák és eladnák a lakossági befektetők a portfóliójukban szereplő állampapírokat. A nemzetközi hatások esetén a negatív világgazdasági sokkban komolyabb kockázatot lát a lakosság, mint egy regionális görög fizetésképtelenségben. Egy újabb görög válság esetén közel 60 százalék nem változtatna a magyar államkötvény-pozícióján, míg globális visszaesés esetén már csak kevesebb mint a fele tartana ki. A nyájhatás mérése érdekében vetettük fel, hogy mit tennének a válaszadók, ha egy neves befektető, a hazai lakossági szereplők többsége vagy a megbízhatóság és a prudencia szinonimájaként is értelmezhető, „német” intézményi befektető veszi az állampapírt. Mindegyik hír képes megmozgatni az állampapírpiacot, de úgy tűnik, hogy a lakosság több mint fele nem változtatna állampapír-pozícióján. A német szereplő és a magyar háztartások vételére a válaszadók közel ötöde követné a mintaadó magatartást, míg a neves befektetőre alig 10 százalék reagálna ugyanígy. Kijelenthető tehát, hogy a magyar államkötvénypiac 
hazai lakossági szegmense stabilizáló tényező a magyar államadósság-menedzsment számára. Így a nagyobb hazai lakossági arány növeli a magyar állampapír-piac válságállóságát és védettségét a pénzügyi spekulációval szemben.

A kutatás feltárta, hogy politikai okok és politikai érzelmek is megjelennek a magyar állampapírpiacon. A válaszadók bizonyos csoportjai kifejezetten nem gazdasági, hanem politikai-érzelmi töltettel magyarázta azt, hogy nem vásárolt állampapírt. Alapvetően a kormányt elutasítók közül kerültek ki az államkötvényt politikai okokból elutasítók. Kimutatható volt ugyanakkor ennek ellentéte, az értékpapír-piaci nacionalizmus is. Eredményeink alapján az érzelmek, a gazdasági nacionalizmus, illetve a nemzeti érzület jelentös szerepet játszanak az állampapírpiacon is. A lakossági válaszadók több mint negyede egyetért azzal, hogy egy magyar embernek hazafias kötelessége magyar állampapírt venni, ez egy újabb példája annak, hogy a lakossági befektetők egyes köreinek viselkedését magyarázó tényezők túlmutatnak a hozammaximalizáló gazdasági racionalitáson.

A kutatás egyik mellékeredménye, amely esetleg további felmérések tárgya lehet, a következő: Valószínúsíthető az, hogy a lakosság nem tankönyvszerúen értelmezi a kockázatot. Az ingatlan és az arany számukra kevésbé kockázatos, mint az állampapír. Szoros összefüggés mutatkozik a különbözö befektetési eszközök kockázatosságának megitélése és az állami garancia ismerete között. Akik az állampapírt a legkockázatosabb befektetési eszköznek tartották, azoknak több mint kétharmada nem tudott a garanciáról.

\section{Felhasznált irodalom}

Amadi, A. A. (2004): Does familiarity breed investment? An empirical analysis of foreign equity holdings. An Empirical Analysis of Foreign Equity Holdings, April 6.

Anderson, C. W. - Fedenia, M. - Hirschey, M. - Skiba, H. (2011): Cultural influences on home bias, and international diversification by institutional investors. Journal of Banking \& Finance, 35(4): 916-934. https://doi.org/10.1016/j.jbankfin.2010.09.006

Arnott, R. D. - Chaves, D. B. (2012): Demographic changes, financial markets, and the economy. Financial Analysts Journal, 68(1): 23-46. https://doi.org/10.2469/faj.v68.n1.4

Baker, M. - Wurgler, J. (2006): Investor sentiment and the cross-section of stock returns. The Journal of Finance 61(4): 1645-1680. https://doi.org/10.1111/j.1540-6261.2006.00885.x

Bakshi, G. S. - Chen, Z. (1994): Baby boom, population aging, and capital markets. Journal of Business, Volume 67, Issue 2, April: 165-202. https://doi.org/10.1086/296629

Barber, B. M. - Odean, T. (2001): Boys will be boys: Gender, overconfidence, and common stock investment. Quarterly journal of Economics, Volume 116, Issue 1, 1 February: 261292. https://doi.org/10.1162/003355301556400 
Beugelsdijk, S. - Frijns, B. (2010): A cultural explanation of the foreign bias in international asset allocation. Journal of Banking \& Finance, 34(9): 2121-2131.

https://doi.org/10.1016/j.jbankfin.2010.01.020

Brown, K. C. - Harlow, W. V. - és Tinic, S. M. (1988): Risk aversion, uncertain information, and market efficiency. Journal of Financial Economics, 22(2): 355-385.

https://doi.org/10.1016/0304-405X(88)90075-X

Coval, J. D. - Moskowitz, T. J. (1999): Home bias at home: Local equity preference in domestic portfolios. Journal of finance, 54(6): 2045-2073. https://doi.org/10.1111/0022-1082.00181

Davis, E. P. - Li, C. (2003): Demographics and financial asset prices in the major industrial economies. ResearchGate https://www.researchgate.net/publication/4799298. Letöltés ideje: 2016. augusztus 14.

Ferreira, M. A. - Matos, P. (2008): The colors of investors' money: The role of institutional investors around the world. Journal of Financial Economics, 88(3): 499-533.

https://doi.org/10.1016/j.jfineco.2007.07.003

Grinblatt, M. - Keloharju, M. (2001): How distance, language, and culture influence stockholdings and trades. Journal of Finance, 56(3): 1053-1073.

https://doi.org/10.1111/0022-1082.00355

Guiso, L. - Sapienza, P. - Zingales, L. (2004): Cultural biases in economic exchange (No. w11005). National Bureau of Economic Research. https://doi.org/10.3386/w11005

Harrington Jr, J. E. (1993): Economic policy, economic performance, and elections. The American Economic Review, 83(1): 27-42.

Hofstede, G. (2001): Culture's consequences: Comparing values, behaviors, institutions and organizations across nations. Sage Publications.

Huang, T. - Wu, F. - Yu, J. - Zhang, B. (2015): International political risk and government bond pricing. Journal of Banking \& Finance, 55: 393-405. https://doi.org/10.1016/ j.jbankfin.2014.08.003

Kang, H. C. - Lee, D. W. - Park, K. S. (2010): Does the difference in valuation between domestic and foreign investors help explain their distinct holdings of domestic stocks? Journal of Banking \& Finance, 34(12): 2886-2896. https://doi.org/10.1016/j.jbankfin.2009.11.020

Kang, J. K. (1997): Why is there a home bias? An analysis of foreign portfolio equity ownership in Japan. Journal of Financial Economics, 46(1): 3-28. https://doi.org/10.1016/S0304405X(97)00023-8

Karlsson, A. - Nordén, L. (2007): Home sweet home: Home bias and international diversification among individual investors. Journal of Banking \& Finance, 31(2): 317-333. https://doi.org/10.1016/j.jbankfin.2006.04.005 
Kothari, S. P. - Shanken, J. (1997): Book-to-market, dividend yield, and expected market returns: A time-series analysis. Journal of Financial Economics, 44(2): 169-203. https://doi.org/10.1016/S0304-405X(97)00002-0

Laborda, R. - Olmo, J. (2014): Investor sentiment and bond risk premia. Journal of Financial Markets. 18: 206-233. https://doi.org/10.1016/j.finmar.2013.05.008

Legg Mason (2015): The secret lives of investors: Lessons from behavioral finance. https:// www.leggmason.com/content/dam/legg-mason/documents/en/insights-and-education/ brochure/lessons-from-behavioral-finance.pdf. Letöltés ideje: 2016. augusztus 14.

Markowitz, H.M. (1959): Portfolio Selection: Efficient Diversification of Investments. New York: John Wiley \& Sons. (2nd ed. Basil Blackwell, 1991)

Martell, R. (2008): Understanding Common Factors in Domestic and International Bond Spreads. Review of Finance, 12(2): 365-389. https://doi.org/10.1093/rof/rfn004

Medvegyev Péter (2009): A származtatott termékek árazása és annak problémái az egyensúlyelmélet szempontjából. Közgazdasági Szemle, 56(6): 769-789.

Medvegyev Péter (2010): A hasznossági függvények és a kockázatsemleges mérték. Hitelintézeti Szemle, 9(6): 487-496.

Merton, R. (1972): An analytic derivation of the efficient portfolio frontier. Journal of Financial and Quantitative Analysis, 7(4): 1851-1872. https://doi.org/10.2307/2329621

Modigliani, F. - Brumberg, R. (1954): Utility analysis and the consumption function: An interpretation of cross-section data. In: Kurihara, K. K. (ed.) Post Keynesian Economics. New Brunswick: Ruthers University Press. pp. 383-436.

Moser, C. (2007): The impact of political risk on sovereign bond spreads-evidence from Latin America. https://www.econstor.eu/bitstream/10419/19887/1/Moser_revised.pdf. Letöltés ideje: 2016. augusztus 14.

Neal, R. - Wheatley, S. M. (1998): Do measures of investor sentiment predict returns? Journal of Financial and Quantitative Analysis, 33(04): 523-547. https://doi.org/10.2307/2331130

Pantzalis, C. - Stangeland, D. A. - Turtle, H. J. (2000): Political elections and the resolution of uncertainty: the international evidence. Journal of banking \& finance, 24(10): 1575-1604. https://doi.org/10.1016/S0378-4266(99)00093-X

Šević, A. - Brawn, D. (2015): Do demographic changes matter? A cross-country perspective. Journal of Multinational Financial Management, 30: 36-61. 


\section{Melléklet}

A közvélemény-kutatás során feltett kérdések:

1. Ön szerint az alábbiak közül melyik a legkevésbé kockázatos befektetés?

1) részvény

2) államkötvény

3) vállalati kötvény

4) arany

5) ingatlan

2. Ön szerint az alábbiak közül melyik a legkockázatosabb befektetés?
1) részvény
2) államkötvény
3) vállalati kötvény
4) arany
5) ingatlan

Ön szerint az állam garantálja-e az állampapírba fektetett tőke visszafizetését?
1) igen
2) nem
3) nem tudom/nem válaszol

4. Ön szerint jár-e adókedvezmény vagy járulékkedvezmény az állampapírok hozamára?
1) igen
2) nem
3) nem tudom/nem válaszol

5. Ön szerint a bankbetétnek vagy az állampapíroknak magasabb a hozama?
1) bankbetét
2) állampapír
3) nem tudom/nem válaszol 
6. Ön szerint mennyibe kerül állampapírt jegyezni?
1) díjmentes
2) az ügylet értékének fél százaléka
3) az ügylet értékének egy százaléka
4) nem tudom/nem válaszol

7. Van-e önnek megtakarítása magyar állampapírban? (egy választ válasszon ki, a legjellemzőbbet)

1) Nincs semmilyen megtakarításom

2) Nem, mert nagyobb kockázatú és hozamú befektetéseket keresek.

3) Nem, mert nem ismerem a magyar állampapírok kondícióit és kockázatait.

4) Nem, mert túl kockázatosnak tartom.

5) Nem, mert ennek a kormánynak nem adok egy fillért sem hitelbe.

6) Igen, mert biztonságos, kockázatmentes befektetésnek tartom.

7) Igen, mert nem nagyon ismerem a többi befektetési formát.

8) nem tudom/nem válaszol

8. Van-e megtakarítása magyar állampapírban?
1) igen
2) nem
3) nem válaszol

9. Igaz-e Önre az alábbi állítás megtakarítási döntései esetén?

Ha meg tudok takarítani, automatikusan bankbetétbe vagy állampapírba fektetek. Nem nézem a hozamokat és a kondíciókat.
1) igen
2) nem
3) nem tudom/nem válaszol

10. Igaz-e Önre az alábbi állítás megtakarítási döntései esetén?

Ha kapok egy tuti tippet, azonnal abba fektetem a pénzem.
1) igen
2) nem
3) nem tudom/nem válaszol 
11. Igaz-e Önre az alábbi állítás megtakarítási döntései esetén?

Általában másra bízom a döntést.
1) igen
2) nem
3) nem tudom/nem válaszol

12. Milyen célból takarít meg magyar állampapírban? (több válasz is elfogadható)

1) még nem tudom, mire, de tartalékolok.

2) Ingatlanvásárlásra, házépítésre, drágább, tartós fogyasztási cikkre vagy gépkocsira gyűjtök.

3) Vállalkozási célra gyűjtök.

4) Gyerekeim/unokáim finanszírozására, örökségére gyújtök.

5) Tartozásom visszafizetésére gyűjtök.

6) Időskoromra, nyugdíjas éveimre gyújtök.

7) Utazásra gyűjtök.

8) A háztartásom váratlan kiadásaira tartalékolok.

9) nem válaszol

13. Ha nincs megtakarítása magyar állampapírban, miért? (több válasz is lehet.)

1) Nincs megtakarítható pénzem.

2) Nem bízom a magyar állam fizetőképességében.

3) Ezeknek a politikusoknak egy fillért nem adok kölcsön.

4) A magyar állampapírok nem fizetnek számomra elegendő hozamot.

5) Az állampapír unalmas, szeretek kockáztatni.

6) Nem tudom, hogy lehet magyar állampapírban megtakarítani.

7) Inkább bankszámlán tartom a pénzem.

8) nem tudom/nem válaszol

14. Milyen gyakran foglalkozik a befektetései állásával?

1) naponta többször

2) naponta egyszer

3) hetente

4) havonta

5) ritkábban, mint havonta 
6) nem foglalkozom vele

7) nincsenek befektetéseim

8) nem tudom/ nem válaszol

15. Ön menyire tartja magát jó befektetőnek az átlaghoz képest?

1) átlag feletti

2) átlagos

3) átlag alatti

4) nem tudom/ nem válaszol

16. Az ön életfelfogására, befektetői szemléletére milyen állítás jellemző az alábbiak közül?

1) Nem foglalkozom befektetési kérdésekkel, a pénz lényegtelen az életemben.

2) A megtakarításoknál kerülendő a magas kockázat. Inkább a tőke garantált visszafizetése fontos, a hozamok másodlagosak.

3) Az életben szükséges a kockázatvállalás. Átlátom, és ezért vállalom a kockázatosabb befektetéseket is.

4) Keresem a kockázatos befektetéseket, mert így tudok gyorsan meggazdagodni.

5) nem tudom/ nem válaszol

17. Ön honnan tájékozódik pénzügyi kérdésekben?

1) rendszeresen konzultálok pénzügyi szakemberrel

2) internetről, újságból

3) közeli barátaim, rokonaim, munkatársaim adnak tippeket

4) csak a saját megérzéseimre hallgatok

5) nem foglalkozom ilyen kérdésekkel

6) nem tudom/nem válaszol

18. Tegyük fel, hogy van 1 millió forintja állampapírban évente biztos 5 százalék hozammal. Egy üzleti ajánlatot kap, amelyben 50-50 százalék az esélye, hogy harmadával növeli a tőkéjét vagy harmadát elveszti a tőkéjének. Eladná-e az államkötvényt, hogy az üzleti lehetőségbe befektessen?

1) igen

2) nem

3) nem tudja/nem válaszol 
19. Tegyük fel, hogy van 1 millió forintja állampapírban évente biztos 5 százalék hozammal. Egy üzleti ajánlatot kap, amelyben 50-50 százalék az esélye, hogy másfélszeresére növelje vagy megfelezze a tőkéjét. Eladná-e az államkötvényt, hogy az üzleti lehetőségbe befektessen?

1) igen

2) nem

3) nem tudja/nem válaszol

20. Tegyük fel, hogy van 1 millió forintja állampapírban évente biztos 5 százalék hozammal. Egy üzleti ajánlatot kap, amelyben 50-50 százalék az esélye, hogy 10 százalékkal növeli a tőkéjét vagy 10 százalékot elveszít a tőkéjéből. Eladná-e az államkötvényt, hogy az üzleti lehetőségbe befektessen?

1) igen

2) nem

3) nem tudja/nem válaszol

21. Ha az Ön által tartott állampapírt leminősítené egy hitelminősítő intézet, akkor Ön erre mit lépne?

1) Többet vennék a várható hozamnövekedés miatt.

2) Eladnám azonnal az összes állampapírt és biztonságosabb eszközbe tenném.

3) Eladnám az állampapír egy részét és más eszközbe is fektetnék, hogy megosszam a kockázatot.

4) Tartanám továbbra is az eddigi állampapír-mennyiséget.

5) nem tudom/nem válaszol

22. Tegyük fel, hogy Önnek van 1 millió forint értékű, két év múlva lejáró magyar államkötvénye. Ha Görögország újabb adósságválságba kerül, akkor Ön a magyar állampapírokkal mit tenne?

1) Vennék.

2) Eladnék.

3) Tartanám (se nem vennék, se nem adnék el)

4) nem tudom/nem válaszol 
23. Tegyük fel, hogy Önnek van 1 millió forint értékű, két év múlva lejáró magyar államkötvénye. Egy újabb globális gazdasági visszaesés bekövetkeztekor Ön a magyar állampapírokkal mit tenne?

1) Vennék.

2) Eladnám.

3) Tartanám (se nem vennék, se nem adnék el)

4) nem tudom/nem válaszol

24. Tegyük fel, hogy Önnek van 1 millió forint értékű, két év múlva lejáró magyar államkötvénye. Azt olvasná, hogy egy neves befektető veszi a magyar állampapírt. Ön a magyar állampapírokkal mit tenne?

1) Vennék.

2) Eladnék.

3) Tartanám (se nem vennék, se nem adnék el)

4) nem tudom/nem válaszol

25. Tegyük fel, hogy Önnek van 1 millió forint értékű, két év múlva lejáró magyar államkötvénye. Azt olvassa, hogy a magyar háztartások többsége veszi a magyar állampapírt. Ön a magyar állampapírokkal mit tenne?
1) Vennék.
2) Eladnék.
3) Tartanám (se nem vennék, se nem adnék el).
4) nem tudom/nem válaszol

26. Tegyük fel, hogy Önnek van 1 millió forint értékű, két év múlva lejáró magyar államkötvénye. Azt olvassa, hogy egy német befektetési alap veszi a magyar állampapírt. Ön a magyar állampapírokkal mit tenne?
1) Vennék.
2) Eladnék.
3) Tartanám (se nem vennék, se nem adnék el).
4) nem tudom/nem válaszol 
27. Mit tenne, ha egy Önhöz közelálló személy Önnel ellentétes álláspontot fejtene ki befektetési kérdésben?

1) Megváltoztatnám a befektetési döntésemet, igazat adva neki.

2) A saját döntésemhez ragaszkodnék, és annak helyességét igyekezném igazolni.

3) Lelkileg megviselne, rosszul esne a kritika, összezavarodnék.

4) nem tudom/nem válaszol

28. Ön egyetért azzal, hogy magyar embernek hazafias kötelessége magyar állampapírt venni?

1) egyetértek

2) nem értek egyet

3) nem tudom/ nem válaszol

29. A megtakarítás melyik módját választaná az alábbiak közül, ha a jelenlegi vagyonának feléről (vagy ha nincs vagyona, akkor fél éves jövedeleméről) kellene döntenie öt éves időtávban?

1) Ötéves államkötvénybe fektetném, biztos 5 százalékos hozammal.

2) Ingatlant vásárolnék (beszállnék ingatlanvásárlásba) és kiadnám, vállalva az ingatlanpiaci esetleges leértékelődés kockázatát, az időszakos felújítási költségeket és a bérlők esetleges elmaradását a következő 5 évben.

3) Részvénybe fektetném: a kilátások szerint vagy megduplázódik, vagy megfeleződik a részvény ára a következő öt évben.

4) Devizakereskedésbe szállnék be nagy tőkeáttétellel, amely miatt, ha veszteségem lesz, még a maradék vagyonomat is meghaladó tartozásom is keletkezik, vagy megtízszerezem a pénzem, ha nyereséges leszek. A kilátások szerint vagy leértékelődik a valuta, vagy felértékelődik ugyanakkora eséllyel.

5) Beszállnék egy pókerjátszmába, vagy szerencsejátékba, vagy sportfogadásba, ahol vagy elvesztem a feltett pénz egészét, ami már sehogyan sem nyerhető vissza, vagy megszázszoroznám a pénzemet.

9) nem tudom/ nem válaszol 